\title{
Racionalidade substantiva no processo decisório: um estudo em instituições que lidam com o tratamento oncológico infantojuvenil na cidade de Natal (RN)*
}

\author{
Miriam Soares de Oliveira e Silva** \\ Antônio Sérgio Fernandes***
}

Sumário: 1. Introdução; 2. Racionalidade substantiva; 3. Revisão do tema; 4. Casos; 5. Análise; 6. Conclusão.

Summary: 1. Introduction; 2. Substantive rationality; 3. Theme review; 4. Cases; 5. Analysis; 6. Conclusion.

Palavras-chave: racionalidade; tomada de decisão; isonomia; categorias de análise.

KEY WORDS: rationality; decision making; isonomy; analysis categories.

O presente trabalho trata de um estudo sobre a racionalidade substantiva no processo decisório em duas instituições que lidam com o tratamento oncológico em crianças e adolescentes na cidade de Natal, no estado do Rio Grande Norte. A partir de uma revisão de literatura sobre a racionalidade substantiva, o objetivo da pesquisa é perceber aspectos relacionados ao processo decisório que possam servir de base para elaborar as categorias de análise do processo Tomada de Decisão, agregando-as a um novo estudo que possa proporcionar o avanço do tema na ciência administrativa. Serviram de base para o aprofundamento do tema os trabalhos acadêmicos que seguiram o modelo de análise elaborado por Maurício Serva, cujo quadro verifica a racionalidade predominante em 11 processos administrativos internos em organizações produtivas. Tendo como base teórica a obra de Guerreiro Ramos, que constata a existência de um tipo de organização ideal, o estudo recorre ao pensamento de

\footnotetext{
* Artigo recebido em dez. 2009 e aceito em dez. 2010.

** Professora do Curso Superior de Tecnologia em Gestão Pública do Instituto Federal do Rio Grande do Norte (IFRN). Mestre em administração pela Universidade Federal do Rio Grande do Norte (UFRN). Endereço: IFRN-Diretoria Educacional de Tecnologia da Gestão e da Informação, av. Salgado Filho, 1559 - CEP 59015-000, Natal, RN, Brasil. E-mail: miriamspr@hotmail.com. *** Professor adjunto e pesquisador do PPGA/UFRN e do PPEUR/UFRN. É doutor em Ciência Política pela Universidade de São Paulo e no momento está em estágio pós-doutoral na Universidade do Texas at Austin na Lyndon B. Johnson School of Public Affairs. E-mail: antoniosergio07@gmail.com.
} 
Karl Polanyi, que procura compreender o fenômeno econômico independente do valor que permite considerar economias não mercantis. Para melhor compreender a racionalidade resgatam-se os estudos de Max Weber, que investiga o significado de ação social, e com Jürgen Habermas se tem uma concepção mais abrangente de razão através da teoria da ação comunicativa. Como resultado da revisão do tema foi elaborado um quadro com sete categorias de análise que, aplicadas nas instituições pesquisadas, tornou possível conhecer a racionalidade predominante no processo decisório. Os resultados da pesquisa confirmam que, embora a decisão envolva elementos racionais, existem também valores específicos de cada indivíduo ligados à sua experiência de visão de mundo, permeados não só pela racionalidade instrumental como também pela racionalidade substantiva. O estudo comprovou que duas instituições pertencentes ao mesmo setor podem apresentar diferentes tipos de racionalidade na tomada de decisão, quando fatores decisórios podem tender para a racionalidade instrumental, de acordo com o pensamento clássico da administração, como também podem emergir da racionalidade substantiva, contribuindo para o processo de emancipação do ser humano na esfera do trabalho.

Substantive rationality on decision making process: a study in institutions that deal with children and teenager cancer treatment in the city of Natal (RN)

This work approaches a study about the substantive rationality on decision making process in two institutions dealing with children and teenagers cancer treatment in the city of Natal, state of Rio Grande do Norte. As of a literature review on substantive rationality, the goal of the research is to bring to knowledge aspects related to decision making process which may serve as a basis to ellaborate categories of analysis on decision making process, aggregating them to a new study which may provide progress of the theme in administrative science. The academic researches that followed the analysis model created by Maurício Serva served as a basis to probe such theme, which verifies the predominant rationality in eleven administrative process which are internal in productive organizations. As a theoretical basis, the research has studied the work of Guerreiro Ramos which finds the existence of a type of ideal organization; and it also calls upon the thoughts of Karl Polanyi, who intends to understand the independent economical phenomenon of the value which enables to consider non-market economies. To better comprehend the rationality, the study rescues the research of Max Weber, who investigates the meaning of social action, and also Jürgen Habermas', in which there is a broader concept of the reason through comunicative action theory. As a result of the theme's review, it has been ellaborated a board with seven analysis categories, that when applied in the researched institutions, enabled to know the prodominant rationality in decision making process. The results of the study confirmed that, although the decision involves rational elements, there are also specific values of each individual that are connected to his/her personal experience and point of view, permeated not only by instrumental rationality, but also by substantive rationality. The study has verified that two institutions which belong to the same section may present different types of rationality in decision making, when decision making factors may tend to instru- 
mental rationality, according to the classic theory of administration, as well as it can emerge from substantive rationality, contributing to the process of emancipation of the human being in work environment.

\section{Introdução}

Desde os estudos de Guerreiro Ramos sobre a racionalidade substantiva que diversas pesquisas têm sido conduzidas com o objetivo de compreender a razão como fundamento das ações humanas. Estudar o fenômeno das organizações substantivas a partir de sua racionalidade é conhecer sua lógica interna e contribuir para colocar em evidência elementos da subjetividade humana.

A partir da pesquisa realizada por Serva (1997b) sobre a racionalidade substantiva demonstrada na prática administrativa, vários estudos decorreram da aplicabilidade do modelo teórico desenvolvido em seu trabalho, dando continuidade aos princípios teóricos que questionam a razão na administração. Foram estudos que focaram na prática administrativa, ou seja, como a razão substantiva se concretiza na tomada de decisão, na divisão do trabalho, no controle, no estabelecimento de normas, na comunicação e em outras variáveis de natureza administrativa.

Visando aprofundar o estudo da racionalidade substantiva demonstrada na prática administrativa, o presente artigo focou no processo decisório, que antes era limitado pela distribuição formal de autoridade e que ultimamente tem assumido um caráter mais participativo diante da impossibilidade de coordenação das diferentes ações individuais. De acordo com Serva (1997b), o processo decisório é um dos elementos desarticuladores das organizações burocráticas e se caracteriza, entre outros fatores, por uma administração mais participativa.

A partir de uma revisão do tema realizada em estudos sobre o processo decisório, foram formuladas sete categorias de análise que permitiram observar o processo em questão em duas instituições que lidam com o tratamento oncológico infantojuvenil na cidade de Natal (RN). Para tanto, foi aplicada uma pesquisa qualitativa nas instituições pretendidas que após a análise dos dados permitiu identificar que diferentes racionalidades podem influenciar no processo decisório. Trata-se de um estudo que procura analisar e entender melhor as ações do indivíduo no meio organizacional, com o objetivo de salientar novos aspectos administrativos que permitam a atualização dos indivíduos independente de prescrições impostas.

Através do estudo pode-se concluir que, mesmo em se tratando de instituições de natureza semelhante, a racionalidade predominante no processo 
decisório pode se diferenciar e, principalmente, pode ser comprovada empiricamente, quando fatores decisórios podem emergir também da racionalidade substantiva, gerando ações e atitudes que possam contribuir para a realização e emancipação do ser humano não só na esfera do trabalho, como também em todo o contexto social.

O artigo é composto por mais cinco seções além desta introdução, apresentando na seção seguinte os alicerces teóricos da racionalidade substantiva além do modelo de análise de Mauricio Serva; na terceira seção é feita a revisão do tema através dos trabalhos que focaram a prática administrativa, como também se apresenta a justificativa do processo escolhido e suas categorias de análise; a quarta seção faz uma breve apresentação dos casos pesquisados; na quinta seção é mostrada a análise dos dados e na sexta e última é realizada a conclusão do estudo.

\section{Racionalidade substantiva}

Em sua obra A nova ciência das organizações (1989), Ramos constata um tipo de organização denominada isonomias, que pode ser definida como um contexto em que todos os membros são iguais e onde há uma igualdade de normas.

Para dar base a seu conceito de isonomias, Ramos recorre ao pensamento de Karl Polanyi em A grande transformação, que descobre que a economia do homem, como regra, está submersa em suas relações sociais, como o fato de que ele age dessa forma para salvaguardar sua situação social, suas exigências sociais, seu patrimônio social, ou seja, o homem valoriza os bens materiais na medida em que eles servem a seus propósitos. Neste sentido, o papel do "homo economicus" é submergido nas relações sociais, onde o indivíduo não age como maximizador dos interesses individuais ou motivado pela posse de seus bens materiais. Assim, os processos de produção e distribuição não estão ligados a interesses específicos relativos à posse de bens. Cada passo do processo está atrelado a certos interesses sociais, que não se apresentam de forma idêntica em todas as comunidades (Polanyi, 2000).

Polanyi (2000) afirma que a ação econômica não pode ser compreendida em termos individualistas, uma vez que é influenciada pelas instituições sociais. Convencido de que existiram diversas modalidades de institucionalização da atividade econômica no tempo e no espaço, o estudioso observa que essa distribuição foi assegurada essencialmente pela existência de princípios de regulação das atividades econômicas como a reciprocidade, a redistribuição, a troca de mercado. 
Para Ramos, o conceito elaborado por Polanyi é uma crítica à centralização do mercado como instituição fundamental da atividade econômica e salienta que essa centralização é válida apenas para as sociedades modernas, já que Polanyi busca evidências históricas de que a atividade econômica sempre esteve embebida em outras atividades do tipo social. Ramos se utilizou do estudo de Polanyi para compreender o fenômeno econômico independente da lei de valor que permite considerar as economias não mercantis.

Ramos empreende um processo de diferenciação fundamental entre concepções distintas da vida humana associada, ou seja, o sociólogo diferencia de forma analítica a racionalidade instrumental e a racionalidade substantiva.

Para desenvolver o tema da racionalidade substantiva, Ramos resgatou os estudos de Max Weber que investigam o significado da ação social. Na teoria weberiana, o homem passa a ter, como indivíduo, significado e especificidade. É o ser humano que dá sentido à sua ação social e estabelece a conexão entre o motivo e a ação, a ação propriamente dita e seus efeitos. Em outras palavras, Weber percebeu que estava sendo dado um novo sentido à palavra razão e que somente as ações com "sentido" (sentido pensado e subjetivo dos sujeitos da ação) podem ser atribuídas à racionalidade (Weber, 1977).

Através dos estudos de Weber, Ramos conclui que a racionalidade substantiva é orientada por valores sociais e está de acordo com pressupostos sociais, não concretizando nenhuma ação humana interessada.

O filósofo e sociólogo alemão Jürgen Habermas, grande herdeiro da teoria crítica, tece uma crítica à racionalidade de Weber, uma vez que a sociedade industrial atual é muito diferente daquela conhecida por ele. Habermas observa que a racionalidade analisada por Weber trata de uma forma específica de associação política não reconhecida, quando as normas e relações interpessoais na esfera privada e as regras sistemáticas de ação racional de propósito determinado tornam-se idênticas ou perdem sua diferenciação e, em consequência, conduzem a um estado de comunicação sistematicamente distorcida entre os seres humanos (Ramos, 1989).

Habermas propõe a necessidade de mudança de paradigma em relação à abordagem tradicional da racionalidade, ou seja, o conceito positivista de razão não se aplica ao campo da moral e da prática, que, neste caso, pressupõe uma concepção muito mais ampla e abrangente de razão, que, segundo o estudioso, pode ser encontrado no conceito de razão comunicativa ou dialógica (Freitag, 1993).

O objetivo de Habermas é desenvolver uma teoria que permita uma práxis social voltada para o conhecimento reflexivo e uma práxis política que questione as estruturas sociais, políticas e econômicas existentes, em outras 
palavras, uma teoria que livre o ser humano dos dogmatismos e que o leve em direção à emancipação (Tenório, 2000).

Em Racionalidade e comunicação, Habermas (2002) esclarece o complexo de estruturas de racionalidade e explica como as várias estruturas se fundem no meio linguístico, através de referências a diferentes modalidades de utilização da linguagem e a tipos de ação correspondente.

Ao realizar a substituição do paradigma da consciência pelo paradigma da linguagem, Habermas ressalta que a linguagem deve ser vista como uma expressão de entendimento num contexto normativo e valorativo. O novo conceito de razão desenvolvido por Habermas traz uma visão subjetiva e autônoma da mesma, que consiste num procedimento argumentativo, pelo qual os sujeitos envolvidos se põem em acordo sobre questões relacionadas a verdade, justiça e autenticidade, buscando o entendimento que norteia a racionalidade substantiva nos procedimentos organizacionais.

Serva observa pontos em comum entre as construções teóricas de Ramos e Habermas, já que o ser humano se destaca em ambas as teorias. Nos estudos de Ramos, a razão é um atributo natural do ser humano, está localizado na psique como recurso potencial. Para Habermas, o potencial da racionalidade se concretiza através da ação comunicativa, em que o indivíduo é capaz de orientar suas ações com base em pretensões de validez intersubjetivamente conhecidas da comunidade que está envolvido (Fraga, 2000).

Serva se utiliza da proposta de Ramos de que, por meio da razão, o indivíduo pode conduzir sua vida pessoal à autorrealização, procurar viver numa possibilidade de equilíbrio em busca da satisfação pessoal, sem desconsiderar o direito dos outros também de fazê-lo. A partir dessa percepção, ele parte para sua pesquisa de campo sobre a racionalidade substantiva, demonstrada na prática administrativa, que resultou na elaboração do quadro de análise com os processos organizacionais que norteia os estudos que caracterizam a primeira geração de trabalhos sobre a racionalidade.

\section{Modelo de análise de Maurício Serva}

O trabalho de Serva teve como ponto de partida a busca pelo tipo ideal de organização mencionada por Ramos, as chamadas isonomias, que, segundo ele próprio, são organizações que apresentam a predominância da razão substantiva.

O estudo sobre a racionalidade substantiva demonstrada na prática administrativa resultou na formulação de um quadro de análise que permite identificar e demonstrar, na prática, como a racionalidade substantiva se con- 
cretiza nas práticas administrativas. O quadro propõe a análise de 11 processos organizacionais como: Hierarquia de Normas, Valores e Objetivos, Tomada de Decisão, Controle, Divisão de Trabalho, Comunicação e Relação Interpessoais, Ação Social e Relações Ambientais. Os considerados complementares tratam da reflexão sobre a organização: Conflitos, Satisfação Individual e Dimensão Simbólica.

Aos processos foram reagrupados os diversos elementos constitutivos de racionalidade, de acordo com sua natureza. O quadro apresenta na primeira coluna os 11 processos organizacionais, e na segunda e terceira colunas, faz-se a distinção dos dois tipos de racionalidade, apontados nos elementos constitutivos da ação racional substantiva que são: autorrealização, que são processos de concretização do potencial inato do indivíduo, complementados pela satisfação; entendimento, que são ações pelas quais se estabelecem acordos e consensos racionais, mediadas pela comunicação livre e coordenando atividades comuns sob a égide da responsabilidade e satisfação; julgamento ético, deliberação baseada em juízos de valor (bom, mau, verdadeiro, falso, certo, errado), que se processa através do debate racional sobre as pretensões de validez emitidas pelos indivíduos nas interações; autenticidade, integridade, honestidade e franqueza dos indivíduos nas interações; valores emancipatórios, trata-se de valores de mudança e aperfeiçoamento do social nas direções do bem-estar coletivo, da solidariedade, do respeito à individualidade, da liberdade e do comprometimento, presentes nos indivíduos e no contexto normativo do grupo; autonomia, trata-se da condição plena dos indivíduos para poder agir e expressar-se livremente nas interações.

Os elementos que constituem a ação instrumental são: cálculo, que se trata da projeção utilitária das consequências dos atos humanos; fins, quando há metas de natureza técnica, econômica ou política (aumento de poder); maximização dos recursos, busca da eficiência e da eficácia máximas, sem questionamento ético, no tratamento dos recursos disponíveis, quer sejam humanos, materiais, financeiros, técnicos, energéticos ou, ainda, de tempo; êxito, resultados, relacionados ao alcance em si mesmo de padrões, níveis, estágios, situações, que são considerados como vitoriosos em face de processos competitivos numa sociedade capitalista; desempenho, relacionado à performance individual elevada na realização de atividades, centrada na utilidade; utilidade, neste sentido, a dimensão econômica considerada na base das interações como um valor generalizado; rentabilidade, medida de retorno econômico dos êxitos e dos resultados esperados; estratégia interpessoal, entendida como influência planejada sobre outrem, a partir da antecipação de suas prováveis reações a determinados estímulos e ações, visando atingir seus pontos fracos. 


\section{Quadro de análise}

\begin{tabular}{|c|c|c|}
\hline $\begin{array}{c}\text { Tipo de racionalidade } \\
\times \\
\text { Processos organizacionais }\end{array}$ & Racionalidade substantiva & Racionalidade instrumental \\
\hline Hierarquia e normas & $\begin{array}{l}\text { Entendimento } \\
\text { Julgamento ético }\end{array}$ & $\begin{array}{c}\text { Fins } \\
\text { Desempenho } \\
\text { Estratégia Interpessoal }\end{array}$ \\
\hline Valores e objetivos & $\begin{array}{c}\text { Autorrealização } \\
\text { Valores emancipatórios } \\
\text { Julgamento ético }\end{array}$ & $\begin{array}{c}\text { Utilidade } \\
\text { Fins } \\
\text { Rentabilidade }\end{array}$ \\
\hline Tomada de decisão & $\begin{array}{l}\text { Entendimento } \\
\text { Julgamento ético }\end{array}$ & $\begin{array}{c}\text { Cálculo } \\
\text { Utilidade } \\
\text { Maximização de recursos }\end{array}$ \\
\hline Controle & Entendimento & $\begin{array}{c}\text { Maximização de recursos } \\
\text { Desempenho } \\
\text { Estratégia Interpessoal }\end{array}$ \\
\hline Divisão do trabalho & $\begin{array}{l}\text { Autorrealização } \\
\text { Entendimento } \\
\text { Autonomia }\end{array}$ & $\begin{array}{c}\text { Maximização de recursos } \\
\text { Desempenho } \\
\text { Cálculo }\end{array}$ \\
\hline $\begin{array}{l}\text { Comunicação e relações } \\
\text { interpessoais }\end{array}$ & $\begin{array}{c}\text { Autenticidade } \\
\text { Valores emancipatórios } \\
\text { Autonomia }\end{array}$ & $\begin{array}{c}\text { Desempenho } \\
\text { Exito/resultados } \\
\text { Estratégia Interpessoal }\end{array}$ \\
\hline $\begin{array}{c}\text { Ação social e relações } \\
\text { ambientais }\end{array}$ & Valores emancipatórios & $\begin{array}{c}\text { Fins } \\
\text { Exito/resultados }\end{array}$ \\
\hline Reflexão sobre a organização & $\begin{array}{l}\text { Julgamento ético } \\
\text { Valores emancipatórios }\end{array}$ & $\begin{array}{l}\text { Desempenho } \\
\quad \text { Fins } \\
\text { Rentabilidade }\end{array}$ \\
\hline Conflitos & $\begin{array}{l}\text { Julgamento ético } \\
\text { Autenticidade } \\
\text { Autonomia }\end{array}$ & $\begin{array}{c}\text { Cálculo } \\
\text { Fins } \\
\text { Estratégia Interpessoal }\end{array}$ \\
\hline Satisfação individual & $\begin{array}{l}\text { Autorrealização } \\
\text { Autonomia }\end{array}$ & $\begin{array}{c}\text { Fins } \\
\text { Exito } \\
\text { Desempenho }\end{array}$ \\
\hline Dimensão simbólica & $\begin{array}{c}\text { Autorrealização } \\
\text { Valores emancipatórios }\end{array}$ & $\begin{array}{c}\text { Utilidade } \\
\text { Exito/resultados } \\
\text { Desempenho }\end{array}$ \\
\hline
\end{tabular}

Fonte: Serva (1997b).

A operacionalização do quadro ocorre em três fases. Na primeira, se dá a detecção dos indicadores presentes nas situações reconstituídas e opiniões expressas nas entrevistas. Na fase seguinte, analisa-se um processo de cada 
vez, reúne todos os indicadores detectados e verifica-se qual deles foi predominante. Por último, identifica-se a intencionalidade da racionalidade substantiva através de um continuum, que situa a organização num determinado ponto do mesmo.

Continuum

\begin{tabular}{|c|}
\hline totalmente elevada \\
mínima \\
baixa \\
média \\
elevada \\
muito elevada \\
totalmente substantiva \\
\hline
\end{tabular}

Fonte: Serva (1997b).

\section{Revisão do tema}

\section{Tomada de decisão}

O enfoque à compreensão organizacional, conhecido como "enfoque tomada de decisão", foi iniciado nos anos 1940 a 1950 pelo ganhador de prêmio Nobel Herbert Simon e colegas como James March, do Instituto de Tecnologia. Explorando os paralelos entre tomada de decisão humana e tomada de decisão organizacional, Simon argumentou que as organizações nunca podem ser perfeitamente racionais, porque seus membros têm habilidades limitadas de processamento de informações (Morgan, 1996).

Tomando a ideia de Simon (1970) de que os processos administrativos são processos decisórios, pois consistem no isolamento de certos elementos nas decisões dos membros da organização, no estabelecimento de métodos de rotina para selecionar e determinar esses elementos e na sua comunicação àqueles por eles afetados, tem-se na tomada de decisão um constante desafio na vida do administrador que lida com as incertezas, podendo este decidir de acordo com a teoria da decisão, baseada totalmente na racionalidade instrumental, ou podendo seguir sua intuição particular para chegar a uma boa decisão. Segundo March e Simon (1981), todo processo decisório humano, 
seja no íntimo de um indivíduo, seja na organização, ocupa-se da descoberta e da seleção de alternativas satisfatórias e, em casos excepcionais, preocupa-se com a seleção de alternativas ótimas.

A decisão envolve elementos racionais, levantamento de informações, consciência dos fatos, identificação de alternativas, escolha de objetivos, mas há também um conteúdo ético já que, por trás das escolhas individuais, há conjuntos de valores específicos e próprios de cada indivíduo ligados às suas experiências e a sua visão do mundo, o que, por sua vez, é permeado não só pela racionalidade instrumental como também pela racionalidade substantiva.

Para Srour (2005), as questões moralmente polêmicas não são únicas ou uniformes; embora exista um modo próprio de tomar decisão, as decisões podem divergir em sua essência dependendo dos valores culturais em questão. Quando isso ocorre, a ética assimilada a uma moral particular fica na dependência das inclinações de cada um. Toda decisão sobre a égide da teoria ética da convicção conduz a um mergulho na consciência moral e a uma ampliação de prescrições coletivamente sancionadas.

Numa tentativa de correspondência mais estreita com o mundo real, economistas tentaram incorporar aspectos de comportamento nas situações de escolha ou decisão como fatores psicológicos e sociológicos que levam os indivíduos a tomar decisões e a agir sem recorrer à maximização de utilidade no sentido econômico e clássico (Miller e Starr, 1972). A definição subjetiva de utilidade, que apesar de um conjunto de circunstâncias externas idênticas difere de uma pessoa para outra, possibilita a incorporação de todos esses fatores à teoria econômica.

Para Ramos (1989), a decisão é um elemento estruturante do fato administrativo. Em outras palavras, é o ingrediente político que dá sentido e direção à permanente estruturação do fato administrativo e que define estratégias organizacionais de captação, disposição e exploração dos fatores de produção.

Por ser um dos processos organizacionais que tendem para a racionalização instrumental de acordo com o pensamento clássico da administração, a decisão de analisar a rubrica tomada de decisão parte do reconhecimento de uma realidade social multicêntrica com múltiplos critérios substantivos de vida pessoal e uma variedade de padrões de relações interpessoais que caracteriza o enclave isonômico, quando fatores decisórios podem emergir da racionalidade substantiva, gerando ações e atitudes que contribuam para o processo de emancipação do ser humano na esfera do trabalho. 


\section{Categorias de análise}

São consideradas categorias de análise os aspectos relacionados ao processo decisório, detectados nos trabalhos examinados, que serviram de base para a formulação dos indicadores que possibilitaram estudar o processo em questão nas organizações pretendidas.

São categorias de análise do processo decisório: a dicotomia, o significado do elemento utilidade, comunicação, reunião, objetivo na tomada de decisão, o tempo no processo decisório e delegação.

\section{Dicotomia}

A análise do processo decisório em quase todos os trabalhos estudados aponta para uma dicotomia na tomada de decisão. O trabalho realizado por Fraga (2000) comprovou dicotomia na organização observada, a Muri, uma empresa de linha de montagens, que apresentou decisões centralizadas a nível estratégico e participativo e compartilhado nos níveis tático e operacional. O estudo realizado por Lins (2004) na Casa de Apoio à Criança com Câncer Durval Paiva (CACCDP) constata dicotomia entre líderes e comandados no processo decisório, com reduzida participação política da equipe neste processo. A Fundação analisada por Pinto (2001) observou que há, no nível estratégico, certa resistência no envolvimento do corpo funcional como um todo; adota-se um modelo híbrido que se afunila em termos de participação à medida que se avança no caminho da deliberação estratégica, o que caracteriza dicotomia no processo. O trabalho de Valeriano (2006), que estudou o processo decisório na Coopervale, observou que a diretoria traça os planos de ação e a execução é delegada aos gerentes e empregados da cooperativa.

A dicotomia encontrada nos trabalhos analisados confirma a centralização das decisões a nível estratégico, mas observa-se que o processo decisório a nível tático e operacional caminha para a busca do consenso, ou seja, níveis diferentes de decisão tendem a uso de diversas racionalidades.

Para Ramos (1989), a dicotomia presente no processo decisório organizacional leva o espaço a perder a característica de isonomia e contribui para que a racionalidade substantiva seja mínima. 


\section{Significado do elemento utilidade}

No processo decisório, o termo utilidade está relacionado com o resultado alcançado, ou seja, se os recursos foram bem aproveitados para se atingir o objetivo esperado. Neste sentido, o indivíduo age com a finalidade de maximizar suas utilidades, quando a ideia está relacionada ao sentido econômico clássico. Uma definição subjetiva de utilidade tem sido considerada desde que aspectos relacionados ao comportamento humano passaram a ser levados em conta nas situações de escolha ou decisão.

Na pesquisa realizada por Lins (2004) observa-se que o termo utilidade ganha um valor subjetivo à medida que o autor o relaciona com o caráter substantivo da missão organizacional.

Miller e Starr (1972) afirmam que a situação que o tomador de decisão alcança pode ter uma medida de utilidade completamente diferente do que a medida natural indica, ou seja, como afirma Elster (1994), existe um conteúdo ético por trás das escolhas individuais.

\section{Comunicação}

De acordo com a perspectiva habermasiana, a organização burocratizada, enquanto processo organizacional, é, em si mesmo, fator inibidor da competência comunicativa. Na teoria da ação comunicativa de Habermas (2002), a linguagem deve ser vista como uma expressão de entendimento num contexto normativo e valorativo; assim, a razão assume uma forma autônoma que consiste num procedimento argumentativo, aspecto este que pode ser observado nos procedimentos organizacionais.

A pesquisa realizada por Ferreira (2004) deu ênfase à questão da comunicação no ambiente organizacional, já que o principal efeito do uso instrumental da linguagem é a distorção comunicativa no mesmo. Segundo Dejours (2005), a distorção comunicativa é comum no ambiente centrado na lógica instrumental, quando as pessoas são manipuladas para a obtenção do lucro. Neste ambiente, o processo decisório legitima-se pela autoridade formalmente instituída, caracterizando, assim, um sistema hierarquizado de tomada de decisão. Por outro lado, na orientação racional comunicativa, o processo de tomada de decisão legitima-se pelo consenso obtido em espaços de discussão autênticos, onde são privilegiados todos os requisitos para uma interação comunicativa não distorcida. 
De acordo com Ramos (1989), o fenômeno da comunicação distorcida se tornou uma preocupação de Habermas na medida em que o desenvolvimento da forma capitalista de produção restringia a "livre e genuína comunicação" entre as pessoas, ocultando diferenças entre a ação instrumental e a substantiva.

\section{Reunião}

Uma das formas encontradas para a troca de informações, no sentido de identificar e resolver problemas, foram as reuniões, que passaram a ser um aspecto central para dirigir e dominar a atividade diária de trabalho (March e Simon, 1981).

O enfoque mecanicista da organização apresentou tendências a ser abandonadas à medida que condições ambientais de turbulência passaram a ser consideradas; assim, um enfoque mais orgânico e mais flexível em relação à organização foi necessário para o sucesso operacional.

Na revisão do tema, o elemento reunião aparece como um espaço privilegiado para a tomada de decisão. O trabalho realizado por Valeriano (2006) na Cooperativa em Itabira/MG destacou as reuniões como espaço privilegiado e necessário para a tomada de decisão, quando estas podem ocorrer em conjunto, ou seja, baseadas no consenso.

As reuniões também foram destacadas no trabalho de Ferreira (2004), que estudou uma instituição psiquiátrica com diversos espaços para discussão, caracterizando um ambiente participativo dos processos decisórios.

Considerada, portanto, uma categoria do processo decisório, a reunião pode ser vista como um fórum aberto de tomada de decisão, um espaço para troca de ideias, ou simplesmente um espaço para se captar ideias enquanto a decisão final fica sempre centralizada no comando da reunião.

\section{Delegação}

As posições formais no organograma de uma organização definem as esferas de delegação de autoridade. A pirâmide do poder de um organograma pode ser construída sobre o alicerce no qual uma parcela considerável de poder pertence àqueles que se encontram tanto na base como no topo da pirâmide (Morgan, 1996). 
Segundo March e Simon (1981), a prática da delegação resulta em departamentalização e maior bifurcação de interesses entre subunidades da organização, quando estas colocam seus objetivos próprios acima do interesse total da organização.

O ato de delegar é observado no trabalho de Valeriano (2006). A prática da delegação está relacionada diretamente com o processo decisório, quando a decisão é tomada em um determinado nível, e a execução é delegada a outro. O autor observa que o processo de delegação pode possuir elementos da racionalidade instrumental como cálculo e maximização de recursos em alta intensidade.

\section{Objetivo na tomada de decisão}

Segundo Miller e Starr (1972), muitos objetivos têm um amplo espectro de possíveis graus de consecução, mas faltam meios para medi-los, ou seja, podese buscar um objetivo que deve ser alcançado sem possibilidades intermediárias ou podem-se perseguir objetivos que permitam uma escala total de possíveis graus de consecução. Ainda segundo os autores, para alguns objetivos existem maneiras naturais de medir o grau de consecução; para outros, não existe qualquer forma de medir este grau. Neste sentido, os objetivos a serem alcançados, através da tomada de decisão, podem estar relacionados à racionalidade instrumental, como algo que pode ser mensurado, como também podem estar relacionados à racionalidade substantiva.

O estudo de Ferreira (2004), realizado numa instituição psiquiátrica, demonstra que a prática do agendamento dos assuntos a serem tratados não segue nenhum critério hierárquico de assuntos ou de participantes, quando "qualquer um pode agendar qualquer coisa". O que há são as questões ordinárias que podem ser tratadas tanto no início como no final da reunião.

Assuntos de ordem pessoal, como observados na pauta de reunião da organização estudada por Ferreira (2004), dificilmente podem ter o grau de consecução mensurado; portanto, trata-se de objetivos relacionados à racionalidade substantiva, que não tem a presença dos elementos utilidade e maximização de recursos.

\section{Tempo no processo decisório}

Com as mudanças ocorridas na sociedade com a inserção das forças capitalistas, o tempo passou a ser uma variável considerável no aparelho de produção. 
No que diz respeito ao processo decisório, a presença de alguns elementos da racionalidade substantiva, como entendimento e consenso, é vista como aspectos retardadores do processo decisório, ou seja, a postergação nas decisões que muitas vezes travam o bom andamento da organização acontece devido à presença do elemento entendimento na busca pelo consenso.

A pesquisa realizada por Valeriano (2006) na Cooperativa em Itabira observou que a lentidão nas decisões traz implicações diretas nos cooperados, que sofrem com os atrasos nas decisões e que, por sua vez, influencia na própria práxis administrativa da organização. $\mathrm{O}$ autor observa também em sua pesquisa que a pouca influência das reuniões é um fator impeditivo de velocidade nas decisões e ações organizacionais.

\section{Casos}

\section{Grupo de Apoio à Criança com Câncer}

O Grupo de Apoio à Criança com Câncer (GACC) surgiu em meados de 1988, quando um grupo de funcionários do Hospital Infantil Varela Santiago e familiares de pacientes resolveram trabalhar para diminuir algumas carências das crianças que se encontravam em tratamento oncológico naquela instituição.

A entidade tem como missão "prestar assistência psicossocial às crianças com câncer e seus familiares, bem como minimizar as carências financeiras dessas famílias, quanto a questão alimentar, médica/ambulatorial, transporte entre outras".

A instituição oferece hospedagem com cinco refeições diárias, cestas básicas, auxílio para transporte, exames, medicamentos, fraldas descartáveis, suplementos nutricionais, auxílio funeral e entretenimentos, além de todo apoio emocional, social e jurídico às crianças e adolescentes e seus acompanhantes.

O trabalho voluntário tem grande importância na execução dos serviços realizados no GACC, quando este assume responsabilidade e compromisso na realização das tarefas com as quais se compromete. Conta também a ajuda de diversos parceiros, como grande empresas locais que auxiliam principalmente no aspecto financeiro.

O espaço físico que sedia todo esse complexo de atividades é conhecido como "Lar Esperança", uma casa alugada que fica numa rua movimentada na cidade de Natal, onde se realizaram as entrevistas durante todo o mês de novembro e dezembro de 2008. 
Atualmente a sede do GACC mudou-se para o edifício construído para dar mais conforto a crianças e adolescentes que passam pelo tratamento médico.

\section{Casa de Apoio à Criança com Câncer Durval Paiva}

A Casa de Apoio à Criança com Câncer Durval Paiva (CACCDP) é uma instituição sem fins lucrativos que ampara crianças e adolescentes carentes portadoras de câncer, juntamente com um responsável, durante o tratamento em Natal.

A história de sua fundação está relacionada a um drama pessoal que uma família potiguar passou, quando em 1994 foi diagnosticado câncer em seu filho, ainda criança. A família viajou para o exterior e lá recebeu a ajuda de uma entidade que era mantida pela rede McDonald's. Ao voltar, a família resolveu fundar em Natal algo semelhante que pudesse apoiar as crianças em tratamento oncológico.

Entre os serviços, a Casa oferece hospedagem, alimentação, doação de roupas, calçados, brinquedos, cestas básicas, auxílio para a aquisição de medicamento e distribui mensalmente 313 cestas básicas a famílias das crianças em tratamento.

A Casa mostrou-se receptiva aos contatos da pesquisadora, que esteve em uma reunião para apresentar seu estudo e conhecer os profissionais da instituição, que depois participaram ativamente das entrevistas no final do mês de novembro e por todo o mês de dezembro de 2008.

\section{Análise}

\section{Grupo de Apoio à Criança com Câncer}

\section{Dicotomia}

Um dos fatores motivadores dos voluntários como também dos funcionários é saber que estão ajudando crianças que passam pelo tratamento oncológico. Todos se sentem bem em oferecer seu trabalho em prol de uma causa e canalizam suas forças para superar os obstáculos, procurando atingir os objetivos do grupo.

Os assuntos relativos aos planos de ação da instituição estão mais diretamente relacionados à direção, enquanto setores possuem autonomia para 
decidir sobre as questões relativas ao dia a dia de suas atividades e procuram interagir, buscando dividir os problemas no sentido de atingir o que é melhor para as crianças através do entendimento. Quando os assuntos e decisões estão relacionados ao planejamento, as ações da instituição, como também seus problemas, são levadas para a diretoria, que toma decisões através de reuniões.

A tomada de decisão nos níveis tático e operacional é baseada na busca pelo entendimento, ocorrendo de forma participativa e compartilhada entre os setores, que discutem e prezam pelo consenso em suas decisões. Já no nível estratégico, no que se refere ao planejamento, a análise de necessidade de implementação de mudanças na instituição, o processo de decisão concentra-se na diretoria, que discute e estabelece as linhas de ação da instituição, quando estas normalmente são realizadas através de votação, prevalecendo a vontade da maioria, o que caracteriza uma decisão colegiada, baseada no consenso.

Desta forma, o estudo identificou diferentes instâncias decisórias, já que a equipe multidisciplinar está sempre decidindo sobre as questões relacionadas ao dia a dia, mostrando-se como fóruns abertos à discussão, e tem o elemento entendimento como princípio que perpassa as diferentes instâncias decisórias. As decisões relacionadas ao plano estratégico ficam a cargo da diretoria, que também se mostra como fórum aberto à discussão, já que as decisões são realizadas de forma colegiada.

A dicotomia é uma categoria identificada em quase todos os trabalhos que abordaram a rubrica Tomada de Decisão na primeira geração de trabalhos. O trabalho realizado por Marcelo Fraga (2000) analisou uma organização que, no geral, é identificada como "democrática", termo este que aparece várias vezes como um elemento onde prevalece a vontade do grupo na tomada de decisão no nível tático e operacional, enquanto no nível estratégico é centralizada nos diretores. No trabalho realizado por Fábio Ferreira (2004) numa instituição psiquiátrica, a dicotomia aparece como um "duplo comando", mas, segundo o pesquisador, este não se apresenta como uma dificuldade para os funcionários do hospital, já que as atribuições dos dois sistemas são claras.

Segundo March e Simon (1981), é o caráter preciso e impessoal que dá o tom burocrático à instituição, e não o número de níveis de autoridade, o que faz do GACC uma instituição menos burocratizada, já que se observa um bom relacionamento entre todos que convivem no ambiente e procuram contribuir com a missão do grupo.

Embora o GACC tenha apresentado diferentes instâncias decisórias, não se detecta dicotomia no processo decisório, pois o entendimento é o princípio que perpassa por todas elas, contribuindo para que o espaço pesquisado, nesta 
categoria analisada, se aproxime do que Ramos definiu de isonomias, caracterizado pela presença de elementos da racionalidade substantiva.

\section{Significado do elemento utilidade}

Na instituição pesquisada, embora muitas vezes a decisão seja determinada num nível hierárquico superior com sua medida de valor já definida, esta se mostra sempre associada à missão do grupo. Neste sentido, o indivíduo tem sempre espaço para emitir opinião, fazer julgamento ético, podendo este interferir na medida de valor predeterminada anteriormente.

Como afirma Srour (2005), as questões moralmente polêmicas não são únicas e uniformes quando as decisões podem divergir em sua essência, dependendo dos valores culturais em questão.

Confirmando o pensamento de Newton Lins (2004), o termo utilidade ganha valor subjetivo à medida que se relaciona com o caráter substantivo da missão organizacional, que tem seu valor relacionado à vida. Assim, o GACC não apresenta a maximização de recursos como medida de valor de decisão que deve ser tomada, o que caracteriza a presença da racionalidade substantiva na categoria analisada.

\section{Comunicação}

Embora ocorra uma comunicação formal de natureza informacional que pode caracterizar uma comunicação burocratizada, observa-se no dia a dia do GACC a comunicação verbal, baseada na simetria de relações com maior relação de entendimento.

O clima informal predominante no GACC foi observado na pesquisa de Fábio Ferreira (2004), na Instituição Psiquiátrica, que constatou a cordialidade e a liberdade para expressar livremente uma opinião e um sentimento, independente do cargo que se ocupa, o que facilita a relação comunicativa na organização.

Na instituição pesquisada, não é comum presenciar o constrangimento pré-linguístico, podendo este ocorrer, às vezes, em setores isolados, quando se silencia para se aguardar o melhor momento para buscar o entendimento. Tanto funcionário como voluntários, mães e pacientes se sentem à vontade para falar, facilitando a relação de comunicação. 
Como afirma Dejours (2005), a distorção comunicativa é comum no ambiente organizacional centrado na lógica instrumental. No caso da organização pesquisada, o processo é legitimado pelo consenso através dos espaços de discussão autênticos numa interação comunicativa sem distorções e sem constrangimento pré-linguístico. A busca pelo aprimoramento de uma linguagem mais adequada no ambiente organizacional deve ser vista, como afirma Habermas (2002), como a expressão de entendimento num contexto normativo e valorativo.

A simetria nas relações de comunicação que prevalecem nas decisões do dia a dia, o não domínio do constrangimento pré-linguístico, a presença de comunicação verbal e informal na busca de um melhor aprimoramento de processo de comunicação ao ambiente revelam a presença de elementos da racionalidade substantiva na categoria analisada.

\section{Reunião}

As reuniões foram apresentadas pela literatura clássica da administração como um espaço privilegiado para a tomada de decisão, sendo um aspecto central no direcionamento das atividades diárias de trabalho dentro das organizações.

O espaço decisório pode ser considerado como um fórum aberto de tomada de decisão, quando nas reuniões a troca de ideias orienta para uma decisão colegiada. Características importantes da reunião confirmam a natureza do fórum, ou seja, se se trata de um fórum aberto à discussão ou se se apresenta apenas como um espaço de divulgação das decisões, com a centralização do poder decisório. A própria questão da estrutura da reunião, dando ou não destaque ao decisor, como também a possibilidade de abertura, ou não, desse espaço para questões de ordem pessoal, ajudam a revelar a racionalidade predominante no processo organizacional.

O GACC apresenta vários calendários de reunião, como a reunião de diretoria que ocorre mensalmente, a reunião dos voluntários que ocorre também mensalmente, a reunião dos novos voluntários que ocorre uma vez a cada dois meses e a reunião dos setores, como da equipe multidisciplinar, que acontece semanalmente ou de acordo com as necessidades.

As reuniões no GACC são um exemplo de que o enfoque mecanicista da organização foi abandonado, como afirma March e Simon (1981), quando as organizações passam a considerar um enfoque mais orgânico e mais flexível.

$\mathrm{Na}$ instituição pesquisada, as reuniões são consideradas como um espaço para troca de informações, no sentido de identificar e resolver problemas, 
apresentando-se como um fórum aberto às discussões em busca do consenso. Embora seja de praxe privilegiar os assuntos de ordem administrativa, observa-se certa abertura para as questões de ordem pessoal.

Na reunião não há destaque para o decisor, coordenador ou diretor. Os membros ficam dispostos de forma a facilitar uma melhor participação de todos, sem diferenças, onde todos os presentes têm liberdade para falar e emitir sua opinião, debater as questões e alcançar as melhores soluções.

O estudo de Fábio Ferreira (2004) constatou o caráter participativo dos processos decisórios do hospital pesquisado, que de certa forma ocorre graças à postura dos detentores da autoridade formal, que procuram ter 0 reconhecimento do outro como igual, seja buscando sancionar as decisões acordadas nas reuniões de seu grupo, seja tendo um autorreconhecimento como integrante de uma equipe autogerida. Outro aspecto importante ainda observado no mesmo trabalho foi a questão da equidade entre os profissionais, que têm a mesma importância para as crianças em tratamento, perspectiva esta que foi possível graças ao conceito de agente terapêutico. Assim, em se tratando da saúde das crianças, o peso de uma opinião numa reunião é o mesmo para todos, aspecto também observado no GACC.

Sendo considerado por March e Simon (1981) como um espaço necessário para a troca de informações, no sentido de identificar e resolver problemas, a reunião no GACC revela a presença de elementos da racionalidade substantiva em seu procedimento operacional, como também em sua estrutura, que se apresenta como um fórum aberto às discussões, onde as decisões ocorrem, em sua maioria, de forma colegiada e prevalece o elemento entendimento, caracterizando a presença da racionalidade substantiva na categoria analisada.

\section{Objetivo na tomada de decisão}

Os objetivos podem diferenciar na tomada de decisão. Podem ser norteados pela maximização de recursos, representando a presença da racionalidade instrumental, como também podem ser norteados pela reflexão de cunho ético, que caracteriza elementos da racionalidade substantiva.

Na instituição pesquisada, inicialmente busca-se refletir sobre o objetivo proposto na tomada de decisão, vendo-se a melhor forma de atingi-lo, sem desviar da missão do grupo, que é o bem-estar das crianças. Elas (as crianças) norteiam os objetivos na tomada de decisão, são por elas que se tenta alcançálos, muitas vezes dominados pela sentimentalidade de uma piora no estado de saúde ou mesmo de um óbito, mas a exequibilidade do objetivo, muitas vezes, 
depende da maximização de recursos, já que a instituição vive de doação e depende de terceiros para a realização de seus projetos.

Segundo Miller e Starr (1972), os objetivos a serem alcançados através da tomada de decisão podem ser perseguidos numa escala total de possíveis graus de consecução ou não. Ou seja, os objetivos a serem alcançados podem estar relacionados à racionalidade instrumental, como algo que pode ser mensurado ou não; no último caso podem estar relacionados à racionalidade substantiva, quando não se observa a presença dos elementos utilidade e maximização de recursos.

No caso do GACC, os objetivos perseguidos na reunião costumam passar por uma reflexão ética de seus propósitos, o que os coloca numa difícil forma de medir seu grau de consecução, quando quase sempre prevalece a questão relacionada à dimensão da vida, que muito reflete a missão da casa e a razão de ser do grupo.

Para Ramos (1989), a decisão é um elemento estruturante do fato administrativo. Em outras palavras, é o ingrediente político que dá sentido e direção à permanente estruturação do fato administrativo e que define estratégias organizacionais de captação, disposição e exploração dos fatores de produção. Assim, a participação política da equipe no processo decisório do GACC, cujas reflexões de cunho ético norteiam os objetivos dos assuntos em pauta, dificulta mensurar o grau de consecução de seus objetivos devido à missão do grupo, que incentiva o compromisso com o trabalho e a realização pessoal.

Desta forma, os objetivos alcançados na tomada de decisão estão relacionados à racionalidade substantiva, pois não se observa a presença dos elementos cálculo e maximização de recursos; ao contrário, é clara a presença do julgamento ético na categoria analisada.

\section{Tempo no processo tomada de decisão}

O tempo é um fator imprescindível na tomada de decisão como também na execução das ações. Tendo as reuniões como espaço privilegiado para as tomadas de decisões, a frequência com que estas acontecem pode significar, no processo decisório, a presença do elemento entendimento ou não. Ou seja, se as reuniões não acontecem com certa frequência, decisões tendem à centralização, dificultando as decisões colegiadas, baseadas no consenso, o que pode representar a presença da racionalidade instrumental.

No caso do GACC, não foi observada certa sistematização das reuniões, tanto que elas não seguem fielmente o calendário preestabelecido e muitas vezes acontecem para suprir a necessidade de se tomar uma decisão. 
De acordo com a literatura pesquisada, um número maior de reuniões pode facilitar uma administração colegiada, já que as decisões podem passar por uma discussão e chegar a um consenso. O trabalho de José Valeriano (2006) constatou que o fato de a diretoria da Coopervale só se reunir uma vez por semana, mais precisamente às segundas-feiras, apareceu como um elemento impeditivo de velocidade nas decisões da empresa.

A falta de sistematização das reuniões na organização pode levar a decisões centralizadas. Quando acontece de algum assunto não poder aguardar, a decisão pode ficar nas mãos de um único decisor, como pode também levar à postergação nas decisões, com implicações negativas para a operacionalização de setores envolvidos e que aguardam soluções. Neste caso, a falta de sistematização de um calendário de reuniões pode significar a presença da racionalidade instrumental.

No caso do GACC, não é muito comum ocorrer decisões centralizadas. Estas podem acontecer de forma esporádica, devido à própria dinâmica do grupo que, de acordo com sua missão, lida com assuntos que não podem esperar, não constituindo, portanto, um processo rotineiro da organização, quando as decisões geralmente acontecem baseadas no consenso. A instituição busca não postergar suas decisões, quando normalmente os assuntos são resolvidos em reuniões ou nos espaços informais, o que demonstra autonomia dos comandados para decidirem.

O estudo de Fábio Ferreira (2004) observou que as decisões levam tempo para serem tomadas, especialmente quando envolvem opiniões conflitantes. Neste caso, o único fato, segundo o pesquisador, que pode minimizar as dificuldades operacionais é a autonomia dos setores.

Conclui-se que a falta de sistematização do calendário de reuniões não implica a centralização constante do poder decisório, podendo este acontecer sem constituir um processo rotineiro da instituição; no entanto, fica comprovado que a falta de sistematização das reuniões prejudica setores relacionados, o que leva funcionários e voluntários a tomarem decisões centralizadas, mas também, muitas vezes, leva-os a procurar outros espaços para discutir e tomar decisões, caracterizando a presença dos elementos autonomia e responsabilidade. Assim, observa-se a presença tanto da racionalidade instrumental com as decisões centralizadas, como também da racionalidade substantiva através da autonomia e do entendimento.

Os elementos entendimento e autonomia prevalecem na categoria analisada. Embora ocorram decisões centralizadas, estas não constituem um procedimento normal na instituição, o que caracteriza a presença tanto da racionalidade substantiva quanto da racionalidade instrumental na categoria analisada. 


\section{Delegação}

O organograma é um instrumento administrativo que formaliza a hierarquia e a departamentalização da organização, facilitando visualizar as diversas funções e as atribuições de cada setor.

No primeiro contato com a instituição, foi apresentado pelo próprio presidente um organograma das funções do grupo. Ao longo da pesquisa foram constatadas algumas modificações a partir da ausência do administrador, que já não se encontrava mais na instituição com a vacância do cargo e ficou claro que ali as funções não eram tão inflexíveis, ou seja, as funções exercidas pelos funcionários ou mesmo voluntários extrapolavam as linhas de um quadro.

Para a literatura clássica, segundo March e Simon (1981), a maior bifurcação de interesses entre subunidades da organização é o resultado da prática de delegação que está diretamente relacionada ao processo decisório, quando a distribuição de poder nas diversas esferas pode significar a presença da racionalidade substantiva.

O estudo de José Carlos Valeriano (2006) constatou a presença do processo de delegação dentro da atribuição do empregado, dentro do plano de cargos e salários, quando a diretoria toma a decisão de liberar para fazer e os funcionários executam, processo este que traz consigo o elemento cálculo e maximização de recursos em alta intensidade.

Embora o GACC apresente um organograma de suas funções, o que na literatura define as esferas de delegação de autoridade e representa a presença do elemento cálculo, não foi observada ao longo da pesquisa tal departamentalização com delegação de autoridade. Ao contrário, durante a pesquisa observou-se o envolvimento de várias pessoas numa mesma atividade, com autonomia e responsabilidade nas diversas esferas para desenvolver suas funções. Neste sentido, pode-se concluir que na categoria delegação prevalecem os elementos autonomia e responsabilidade que caracterizam a presença da racionalidade substantiva.

\section{Casa de Apoio à Criança com Câncer Durval Paiva}

\section{Dicotomia}

A estrutura divisional da CACCDP é caracterizada por diferentes instâncias decisórias com variados princípios, mostrando-se como um fórum aberto à discussão no nível operacional, baseado no princípio entendimento, quando profissionais 
têm autonomia para decidir em relação a assuntos específicos do seu setor, e apresentando-se como fórum fechado à discussão no nível estratégico, tendo como princípio a unilateralidade, com centralização decisória e imposição de medidas, muitas vezes sem conhecimento prévio dos funcionários.

Entre os profissionais da equipe técnica, existe o diálogo em busca do entendimento para se tomar as decisões relacionadas à criança, que é paciente ou aluno comum a todos os profissionais. A equipe técnica se concretiza como fórum aberto à discussão, já que as diferentes faces do paciente/aluno precisam ser conhecidas através desses profissionais. Os resultados surgem através do diálogo da equipe, no qual prevalece o entendimento. Assuntos de natureza estratégica que envolvem custos são tratados diretamente com a direção, cuja tomada de decisão costuma ser centralizada. Neste sentido, o poder formalmente hierarquizado apresenta-se como primeira instância decisória, sendo um fórum fechado às discussões.

Um dos trabalhos pertencentes à primeira geração analisou a racionalidade dominante na instituição pesquisada. Foi o estudo realizado por Newton Lins (2004), que observou a dicotomia como "água divisória" entre líderes e comandados, já que não se observa uma abrangência na tomada de decisão, quando cada profissional tem autonomia de decisão relacionada apenas a seu setor, e no nível estratégico o poder de decisão é centralizado e legitimado pela autoridade formalmente constituída. Neste sentido, as instâncias decisórias na CACCDP apresentam-se como um fórum aberto à discussão no nível operacional, com destaque para a equipe técnica que dialoga na busca pelo entendimento, enquanto no nível estratégico a decisão não se dá de forma colegiada, ou seja, o poder de decisão é centralizado.

A resistência à participação do corpo funcional observada na análise da fundação estudada, realizada por Wagner Pinto (2001), comprova a dicotomia entre líderes e comandados, quando o modelo híbrido de participação se afunila à medida que se avança no caminho da deliberação estratégica, aspecto este também observado na CACCDP pela presente pesquisa, que constatou a importância do nível gerencial para a instituição como meio para solucionar problemas. Tal aspecto também foi observado no trabalho de José Valeriano (2006), que constatou a importância do nível gerencial no poder decisório, quando os gerentes têm autonomia para decidir até certo nível.

As diferentes instâncias decisórias observadas na instituição pesquisada com diferentes princípios, caracterizada pelo entendimento no nível operacional e centralizada no nível estratégico, denunciam a dicotomia no processo decisório como também a presença da racionalidade instrumental na categoria analisada. 


\section{Significado do elemento utilidade}

Quando a medida de valor que pesa na decisão está relacionada à questão econômica, o elemento utilidade costuma ser associado à maximização de recursos, mas o elemento utilidade pode ter o sentido subjetivo se houver uma variação da medida de valor que pesa na decisão.

Embora a instituição pesquisada não seja uma organização com fins lucrativos, a medida de valor que norteia o processo decisório no nível estratégico é a maximização de recursos na busca constante por resultados. Neste nível, a visão empresarial domina a grande maioria das decisões, enquanto no nível operacional a missão da casa norteia as decisões relacionadas aos setores específicos.

Observou-se, portanto, que o elemento utilidade não sofreu nenhum tipo de variação pelo fato de os funcionários da Casa não terem a oportunidade de exercer o julgamento ético, quando a medida de valor já costuma vir determinada nas decisões impostas pela direção, aspecto este que aparece no trabalho de Newton Lins (2004) com um caráter positivista, já que se utilizam da análise de utilidade, de forma natural e sistemática, objetivando a adoção de práticas e programas que impulsionem a Casa em direção de ganhos em seus objetivos. Assim, o elemento não sofre uma conotação subjetiva, quando a grande preocupação da Casa é alcançar objetivos numa perspectiva mais técnica, mais utilitária, baseada na maximização de recursos.

O significado do elemento utilidade na instituição pesquisada comunga com a literatura clássica da administração, cujo termo utilidade está relacionado com o resultado alcançado, quando o indivíduo age com a finalidade de maximizar suas utilidades, o que demonstra a presença da racionalidade instrumental na categoria analisada.

\section{Comunicação}

Na instituição pesquisada, a comunicação apresenta-se como um processo monológico de natureza informacional. Trata-se de uma comunicação burocratizada com assimetria em suas relações, já que a centralização nas decisões é uma realidade constatada nos discursos dos profissionais da Casa.

O estudo realizado por Wagner Pinto (2001) na Fundação constatou também a centralização nas decisões, cujo pensamento remete para uma preocupação maior em buscar eficácia e eficiência no trato dos recursos dis- 
poníveis. Em outras palavras, a participação dos funcionários nos processos decisórios foi considerada um valor de pouca importância relativa no quotidiano organizacional da Fundação, aspecto este também presente na CACCDP.

O processo decisório na instituição pesquisada é legitimado pela autoridade formalmente constituída. De acordo com a teoria da ação comunicativa de Habermas, a linguagem deve ser vista como uma expressão de entendimento num contexto normativo e valorativo, quando a razão assume uma forma autônoma que pode ser observada nos procedimentos organizacionais. Por outro lado, a organização burocratizada é em si fator inibidor da competência comunicativa, causando, muitas vezes, o constrangimento pré-linguístico, como também provocando a assimetria nas relações de comunicação, aspectos estes que foram constatados nas entrevistas dos funcionários da casa, e que confirmam a presença da racionalidade instrumental na categoria analisada.

\section{Reunião}

Sendo considerado um espaço privilegiado para a tomada de decisão, a reunião pode ser revelada como um fórum aberto à discussão ou não. Neste sentido, faz-se necessário observar não só seu procedimento operacional, como também o próprio aspecto da estrutura da reunião para que seja revelada a racionalidade predominante nesta categoria do processo decisório.

As reuniões foram consideradas um espaço necessário para o sucesso operacional das organizações, podendo-se constituir num espaço para troca de informações, apresentando-se como fórum aberto às discussões, como também podem se constituir num espaço para captação de ideias, enquanto a decisão final fica centralizada no comando da reunião.

Sobre o procedimento operacional das reuniões da CACCDP, foi observado que elas são fechadas para as mesmas pessoas de ordem funcional, com pouca abertura de participação para o público externo.

A reunião da equipe técnica, que reúne os profissionais da Casa que lidam diretamente com as crianças, é vista pelos próprios membros participantes como um espaço para troca de informações, socialização de ideias, apresentação de resultados, como também de outros interesses relacionados à instituição, enquanto as decisões ficam sempre centralizadas na pessoa do diretor. Ainda relacionado à questão operacional da reunião, observou-se que 
assuntos de natureza pessoal não costumam entrar em pauta e, quando isso ocorre, não são tratados com a mesma importância que os demais.

Um dos aspectos observados na pesquisa de José Carlos Valeriano (2006) foi a questão relacionada aos limites das decisões, impostas pela própria diretoria, que trabalha em busca de resultados, influenciada pelos elementos da racionalidade instrumental.

Quanto à estrutura da reunião, observou-se que a hierarquia se reflete na própria disposição dos membros participantes, com destaque para o coordenador ou diretor da reunião. Embora assuntos diversos sejam discutidos pela equipe técnica, a decisão final é centralizada na pessoa do diretor. Desta forma, o processo decisório é legitimado pela autoridade formalmente constituída.

A centralização decisória foi observada na pesquisa de Marcelo Fraga (2000), que constatou um processo eminentemente centralizado na pessoa dos diretores da empresa, cujo planejamento estratégico, leitura e interpretação de cenários, análise da necessidade de implementação de mudanças da organização e decisão sobre novos negócios, ou seja, o estabelecimento de grandes linhas estratégicas de atuação da empresa, está concentrado na pessoa do diretor. Aspecto como este também é constatado na CACCDP, quando a reunião não aparece como um espaço privilegiado para a tomada de decisão, já que estas são sempre centralizadas, o que caracteriza a presença da racionalidade instrumental.

\section{Objetivo na tomada de decisão}

Na tomada de decisão, os objetivos podem ser norteados pela maximização de recursos, quando se busca alcançá-los incondicionalmente, ou podem passar por uma reflexão de cunho ético, quando o indivíduo busca refletir sobre a aplicação de tal objetivo. Neste sentido, os objetivos podem se diferenciar na tomada de decisão, o que demonstra a presença de diferentes racionalidades.

Quando os objetivos a serem alcançados através da tomada de decisão podem ser mensurados em seu grau de consecução, estão assim relacionados à racionalidade instrumental. Trata-se daqueles objetivos que têm a presença dos elementos utilidade e maximização de recursos, portanto, relacionados à racionalidade instrumental.

No caso da CACCDP, a questão relacionada aos objetivos alcançados na tomada de decisão é muito complexa, já que no nível operacional estes passam por uma reflexão ética feita pelos funcionários. Mesmo não possuindo poder 
de decisão a equipe técnica procura discutir e tenta refletir sobre os objetivos propostos.

Quando os objetivos estão relacionados ao saber fazer e não implicam questões diretas com as crianças, busca-se atingi-los incondicionalmente, visando à maximização de recursos. Assim, foi observado que o objetivo na tomada de decisão da CACCDP é norteado pela presença de elementos da racionalidade substantiva, quando a equipe busca fazer uma reflexão sobre os objetivos decisórios relacionados ao bem-estar das crianças. Por outro lado, é observada também a presença da racionalidade instrumental quando se tenta alcançar um determinado objetivo de qualquer jeito, visando à maximização de recursos.

Segundo Miller e Starr (1972), para alguns objetivos organizacionais existem maneiras naturais de medir seu grau de consecução e, para outros, não existe qualquer forma de medir este grau. No caso da instituição pesquisada, os objetivos que passam por uma reflexão ética da equipe técnica dificilmente podem ter seu grau de consecução mensurado, estando assim relacionados à racionalidade substantiva. Por outro lado, os objetivos relacionados à maximização de recursos podem ter seu grau de consecução mensurado e estão relacionados à racionalidade instrumental.

No trabalho de Fábio Ferreira (2004), a participação de membros nos debates, como também a apresentação de propostas em reuniões, revela a dificuldade de medir o grau de consecução dos objetivos, já que estes passam por uma reflexão de julgamento ético.

Na instituição pesquisada, a busca para alcançar objetivos através do cálculo e da maximização de recursos é o princípio que perpassa a categoria analisada, caracterizando a presença da racionalidade instrumental.

\section{Tempo no processo decisório}

O tempo é um aspecto importante a ser observado no processo decisório, quando a frequência com que as reuniões acontecem pode ajudar a revelar se se trata de uma administração colegiada ou não.

Embora na CACCDP as reuniões sigam fielmente um calendário estabelecido pela direção, contando com encontros regulares que acontecem semanalmente, não significa que as decisões se darão sempre baseadas no consenso e não sofrerão atrasos. Ao contrário do que parece, neste caso, o número de reuniões não significa decisões colegiadas, ocorrendo estas sempre de forma 
centralizada. Neste sentido, o fato de a frequência com que as reuniões acontecem não apontar para uma decisão colegiada, como também o fato de a própria dinâmica da instituição, por ter sua missão relacionada à vida, não admitir atrasos nas decisões, somam aspectos que convergem para a centralização decisória. Diante da falta de autonomia decisória dos setores e a ausência do elemento entendimento, pode-se perceber a presença da racionalidade instrumental na categoria analisada.

\section{Delegação}

Tomar uma decisão implica executá-la ou passar essa atribuição na função de delegação de autoridade, o que pode significar a presença do elemento cálculo, ou seja, da racionalidade instrumental, como também pode representar a distribuição de poder nas diferentes esferas, com a presença dos elementos autonomia e responsabilidade, portanto, da racionalidade substantiva.

Embora a CACCDP não apresente um organograma com a departamentalização de suas funções, não significa a presença de autonomia e flexibilidade para os comandados. Ao contrário do que parece na Casa, as funções são bem definidas e reconhecidas por todos que a frequentam. A departamentalização contribui para diminuir a autonomia dos comandados em relação aos setores, o que dificulta as decisões e contribui para maior centralização destas.

Observa-se, portanto, que a departamentalização bem definida dos setores da CACCDP contribui para a falta de autonomia dos funcionários, que não costumam delegar poder a outras esferas. Desta forma, a falta de autonomia e de responsabilidade dos funcionários contribui para detectar a presença da racionalidade instrumental na categoria delegação.

\section{Quadro síntese}

Através do Quadro síntese é possível visualizar melhor as sete categorias de análise do processo decisório, o princípio que perpassa cada categoria da instituição pesquisada e a racionalidade predominante no processo estudado. 


\begin{tabular}{|c|c|c|c|c|}
\hline Categorias & $\begin{array}{c}\text { Princípio que } \\
\text { perpassa a } \\
\text { categoria (GACC) }\end{array}$ & $\begin{array}{c}\text { Princípio que } \\
\text { perpassa a categoria } \\
\text { (DURVAL PAIVA) }\end{array}$ & $\begin{array}{c}\text { GACC } \\
\text { (Racionalidade } \\
\text { predominante) }\end{array}$ & $\begin{array}{l}\text { DURVAL PAIVA } \\
\text { (Racionalidade } \\
\text { predominante) }\end{array}$ \\
\hline 1. Dicotomia & $\begin{array}{l}\text { Diferentes } \\
\text { instâncias } \\
\text { decisórias que têm } \\
\text { como princípio: } \\
\text { Entendimento }\end{array}$ & $\begin{array}{l}\text { Diferentes instâncias } \\
\text { decisórias que têm } \\
\text { como princípio: } \\
\text { a) Equipe Técnica: } \\
\text { Entendimento } \\
\text { b) Direção: Poder } \\
\text { Centralizado }\end{array}$ & $\begin{array}{l}\text { Racionalidade } \\
\text { Substantiva }\end{array}$ & $\begin{array}{l}\text { a) Nível } \\
\text { Operacional: } \\
\text { Racionalidade } \\
\text { Substantiva } \\
\text { b) Nível } \\
\text { Estratégico: } \\
\text { Racionalidade } \\
\text { Instrumental }\end{array}$ \\
\hline $\begin{array}{l}\text { 2. O significado } \\
\text { do elemento } \\
\text { utilidade }\end{array}$ & Julgamento ético & $\begin{array}{l}\text { Maximização de } \\
\text { recursos }\end{array}$ & $\begin{array}{l}\text { Racionalidade } \\
\text { Substantiva }\end{array}$ & $\begin{array}{l}\text { Racionalidade } \\
\text { Instrumental }\end{array}$ \\
\hline 3. Comunicação & Entendimento & $\begin{array}{l}\text { Falta de autonomia } \\
\text { Centralização }\end{array}$ & $\begin{array}{l}\text { Racionalidade } \\
\text { Substantiva }\end{array}$ & $\begin{array}{l}\text { Racionalidade } \\
\text { Instrumental }\end{array}$ \\
\hline 4. Reunião & Entendimento & Centralização & $\begin{array}{l}\text { Racionalidade } \\
\text { Substantiva }\end{array}$ & $\begin{array}{l}\text { Racionalidade } \\
\text { Instrumental }\end{array}$ \\
\hline $\begin{array}{l}\text { 5. Objetivo da } \\
\text { Tomada de } \\
\text { Decisão }\end{array}$ & Julgamento ético & $\begin{array}{l}\text { b) Nível operacional: } \\
\text { Julgamento ético } \\
\text { a) Nível estratégico: } \\
\text { Maximização de } \\
\text { recursos }\end{array}$ & $\begin{array}{l}\text { Racionalidade } \\
\text { Substantiva }\end{array}$ & $\begin{array}{l}\text { Racionalidade } \\
\text { Substantiva } \\
\text { Racionalidade } \\
\text { Instrumental }\end{array}$ \\
\hline $\begin{array}{l}\text { 6. O tempo } \\
\text { na Tomada de } \\
\text { Decisão }\end{array}$ & $\begin{array}{l}\text { Entendimento } \\
\text { Centralização }\end{array}$ & Centralização & $\begin{array}{l}\text { Racionalidade } \\
\text { Substantiva e } \\
\text { Racionalidade } \\
\text { Instrumental }\end{array}$ & $\begin{array}{l}\text { Racionalidade } \\
\text { Instrumental }\end{array}$ \\
\hline 7. Delegação & $\begin{array}{l}\text { Autonomia } \\
\text { Responsabilidade }\end{array}$ & $\begin{array}{l}\text { Cálculo } \\
\text { Centralização }\end{array}$ & $\begin{array}{l}\text { Racionalidade } \\
\text { Substantiva }\end{array}$ & $\begin{array}{l}\text { Racionalidade } \\
\text { Instrumental }\end{array}$ \\
\hline
\end{tabular}

\section{Conclusão}

Das sete categorias analisadas na Tomada de Decisão do GACC, em seis prevaleceram elementos da racionalidade substantiva, enquanto em apenas uma categoria foi observada a presença tanto da racionalidade substantiva quanto da racionalidade instrumental, o que permite concluir que a instituição pesquisada tem suas decisões baseadas no consenso, prevalecendo elementos substantivos como entendimento, autonomia, responsabilidade e julgamento ético.

Tais características classificam o GACC como uma organização que se aproxima da isonomia classificada por Ramos (1989), que a define em um contexto onde todos os membros são iguais. Nas isonomias, seu siste- 
ma de tomada de decisão e de fixação de normas é totalmente abrangente, quando não apresenta diferenciação entre a liderança ou a gerência e os subordinados. Como afirma Ramos (1989), uma isonomia não pode sofrer a dicotomia entre os que tomam a decisão e os que obedecem. Trata-se de uma verdadeira comunidade, onde a autoridade é atribuída por deliberação de todos, onde as atividades são desenvolvidas como vocações e não como um emprego.

De acordo com Serva (1997), o processo decisório é um dos elementos desarticuladores das organizações burocráticas; assim, através do estudo nas duas instituições pode-se comprovar que o GACC é uma instituição menos burocratizada que a CACCDP, já que a primeira apresentou uma administração mais participativa, considerando que suas ações em si não são coordenadas pela direção, existindo autonomia nas decisões que possibilitam a realização do indivíduo. Por outro lado, a CACCDP apresentou centralização nas decisões, sem possibilidade de autonomia para os comandados, características de uma organização burocratizada.

Outro fator de constatação de perda do espaço burocratizado do GACC é a visão habemasiana, cuja teoria afirma que a organização burocratizada é fator inibidor da competência comunicativa. No GAAC, a linguagem é vista como uma expressão de entendimento, não sendo observado o constrangimento pré-linguístico, enquanto na CACCDP as pessoas silenciam e ficam receosas em emitir suas opiniões, já que sabem que a decisão será tomada pela autoridade formalmente constituída.

Segundo March e Simon, o tom burocrático é dado pelo caráter preciso e impessoal e não pelo número de níveis de autoridade apresentado pela organização. Embora o GACC tenha indicado diferentes níveis decisórios, foi observado um bom relacionamento entre todos que convivem no ambiente, indiferente do cargo ocupado, não sendo constatado, portanto, o caráter impessoal presente nas organizações burocráticas.

Através do estudo realizado na CACCDP, pode-se concluir que das sete categorias analisadas na Tomada de Decisão, a racionalidade instrumental apareceu predominante em todas, e em apenas duas categorias a racionalidade substantiva se articula com a racionalidade instrumental, o que permite concluir que a instituição pesquisada tem suas decisões baseadas no elemento cálculo e na maximização de recursos. Embora a CACCDP seja uma organização sem fins lucrativos, observa-se a influência da teoria da decisão que aconselha a maximizar a utilidade esperada, quando as ações são avaliadas e escolhidas não por elas mesmas, mas como meios mais ou menos eficientes para um fim ulterior. 
Conclui-se que este trabalho sobre a rubrica Tomada de Decisão realizado junto a duas instituições que lidam com o tratamento oncológico na cidade de Natal (RN) contribuiu para compreender que diferentes racionalidades influenciam na prática decisória, como demonstrado através das categorias de análise deste processo.

A decisão em analisar a rubrica Tomada de Decisão partiu justamente de acreditar que tais diferenças poderiam existir e, principalmente, poderiam ser comprovadas empiricamente, confirmando o pensamento inicial de que fatores decisórios podem emergir também da racionalidade substantiva, gerando ações e atitudes que possam contribuir para a realização e a emancipação do ser humano não só na esfera do trabalho como também em todo o contexto social.

A rubrica Tomada de Decisão, estudada neste trabalho, apresentou-se como um processo que tanto pode tender para a racionalidade instrumental, de acordo com o pensamento clássico da administração, quando a teoria da decisão aconselha a maximizar a utilidade esperada, como também pode ser permeada por aspectos de comportamento individual, que leva o decisor a tomar decisões sem recorrer à maximização de utilidade no sentido econômico e clássico.

\section{Referências}

BARRETO, César. Sobre a racionalidade humana: conceitos, dimensões e tendências. In: ENAPAD, XVII, Salvador, 1993. Anais... v. 9.

BERTERO, Carlos Osmar. Teoria da organização e sociedades subdesenvolvidas. Revista de Administração de Empresas, São Paulo, v. 32, n. 3, p. 14-28, jul./ago. 1992.

BRAVERMAN, Harry. Trabalho e capital monopolista: a degradação do trabalho no século XX. 3. ed. Rio de Janeiro: LTC, 1987.

CHAUÍ, Marilena. Convite à filosofia. 4. ed. São Paulo: Ática, 1995.

COSTA, Cristina. Sociologia: introdução à ciência da sociedade. 2. ed. São Paulo: Moderna, 1997.

DEJOURS, Christophe. A banalização da injustiça social. 6. ed. Rio de Janeiro: FGV, 2005.

EASTERBY-SMITH, M.; THORPE, R.; LOWE, A. Pesquisa gerencial em administração. São Paulo: Pioneira, 1999. 
ELSTER, Jon. Peças e engrenagens das ciências sociais. Rio de Janeiro: Relume-Dumará, 1994.

ENRIQUEZ, Eugène. Os desafios nas organizações modernas. Revista de Administração de Empresas, São Paulo, v. 37, n. 2, p. 7-17, 1997.

FERREIRA, Fábio. Organizações burocráticas rumo à razão comunicativa: o caso de uma Instituição Psiquiátrica. Dissertação (mestrado em administração) — Universidade Federal do Paraná, Curitiba, 2004.

FRAGA, Marcelo. A empresa produtiva e a racionalidade substantiva: a teoria da ação comunicativa de Jürgen Habermas no ambiente organizacional interativo: de Mary Parker Follett a Collin Porras. Dissertação (mestrado em administração) — Universidade Federal do Rio Grande do Sul, Porto Alegre, 2000.

FREITAG, Bárbara. A teoria crítica: ontem e hoje. 4. ed. São Paulo: Editora Brasiliense, 1993.

GIL, Antônio Carlos. Métodos e técnicas de pesquisa social. 4. ed. São Paulo: Atlas, 1995.

GIL, Antônio Carlos. Métodos e técnicas de pesquisa social. 5. ed. São Paulo: Atlas, 1999.

HABERMAS, Jürgen. O discurso filosófico da modernidade. 1. ed. São Paulo: Martins Fontes, 2002.

HABERMAS, Jürgen. Racionalidade e comunicação. Lisboa: Edições 70, 2002.

LAKATOS, E.; MARCONI, M. Técnicas de pesquisa. 1. ed. São Paulo: Atlas, 1986.

LINS, Newton Manoel. Articulação entre elementos de racionalidade instrumental substantiva nos processos organizacionais da CACC Durval Paiva. Dissertação (mestrado em administração) - Universidade Federal do Rio Grande do Norte, Natal, 2004.

MARCONI, M.; LAKATOS. E. Fundamentos de metodologia cientifica. 6. ed. São Paulo: Atlas, 2007.

MARCONI, M.; LAKATOS, E. Técnicas de pesquisa. 5. ed. São Paulo: Atlas, 2002.

MARCH, James; SIMON, Herbert. Teoria das organizações. 5. ed. Rio de Janeiro: FGV, 1981.

MARTINS, Wellington. Mudança organizacional e ação comunicativa: rumo ao resgate da dignidade e da emancipação humana. Tese (doutorado em administração) - Escola de Administração de Empresas de São Paulo, Fundação Getulio Vargas, São Paulo, 1994. 
MATTAR, Fauze. Pesquisa de marketing. São Paulo: Atlas, 1996.

MILLER, David; STARR, Martin. Estrutura das decisões humanas. 2. ed. Rio de Janeiro: FGV/Instituto de Documentação Serviço de Publicações, 1972.

MORGAN, Gareth. Imagens da organização. São Paulo: Atlas, 1996.

MUDREY, Daniele. Racionalidade e valores: um estudo em duas unidades da rede Uni-Yôga. Dissertação (mestrado em administração) — Universidade do Vale do Itajaí, Santa Catarina, 2006.

PINTO, Wagner. Análise das práticas administrativas de uma fundação empresarial aberta. Dissertação (mestrado) - Curso de Mestrado Executivo, Escola Brasileira de Administração Pública, Fundação Getulio Vargas, Rio de Janeiro, 2001.

PIZZA JÚNIOR, W. Razão substantiva. Revista da Administração Pública, Rio de Janeiro, v. 28, n. 2, 1994.

POLANYI, Karl. A grande transformação: as origens da nossa época. 2. ed. Rio de Janeiro: Elsevier, 2000.

QUIVY, R.; CAMPENHOUDT. L.V. Manual de investigação em ciências sociais. 3. ed. Lisboa: Gradiva, 2003.

RAMOS, Alberto. A nova ciência das organizações: uma reconceituação da riqueza das nações. 2. ed. Rio de Janeiro: Editora FGV, 1989.

RAMOS, Marcos. Racionalidade nas organizações do terceiro setor: tensões e implicações para a avaliação de programas sociais. Dissertação (mestrado em administração) — Universidade de Brasília, Brasília, 2006.

REIS, Liliane. A racionalidade substantiva na avaliação de projetos em ONGs: três casos. Dissertação (mestrado em administração pública) — Fundação Getulio Vargas, Rio de Janeiro, 2001.

REZENDE, Antonio; DIDIER, Maria Tereza. Rumos da história: história geral e do Brasil. 2. ed. São Paulo: Atual, 2005.

SERVA, Maurício. Abordagem substantiva e ação comunicativa: uma complementaridade proveitosa para a teoria das organizações. Revista de Administração Pública, Rio de Janeiro, mar./abr. 1997a.

SERVA, Maurício. A racionalidade substantiva demonstrada na prática administrativa. Revista de Administração de Empresas, São Paulo, v. 37. n. 2, p. 19-30, 1997b.

SERVA, Maurício. Racionalidade e organizações: o fenômeno das organizações substantivas. Tese (doutorado em administração) - Escola de Administração de Empresas de São Paulo, Fundação Getulio Vargas, São Paulo, 1996. 
SEVERO; PEDROZO. A citricultura orgânica na Região do Vale do Caí (RS): racionalidade substantiva ou instrumental? Revista de Administração Mackenzie, v. 9, n. 2, p. 58-81, 2008.

SIMON, Herbert. Comportamento administrativo. Rio de Janeiro: FGV/Instituto de Documentação Serviço de Publicações, 1970.

SILVA, Paulo. Sustentabilidade social: um estudo de caso no mosteiro Monte Carmelo. Dissertação (mestrado em administração) — Pontífica Universidade Católica do Paraná, Curitiba, 2007.

SROUR, Robert Henry. Poder, cultura e ética nas organizações: o desafio da formas de gestão. 13. ed. Rio de Janeiro: Elsevier, 2005.

TENÓRIO, Fernando. Flexibilização organizacional, mito ou realidade? Rio de Janeiro: Editora FGV, 2000.

TENÓRIO, Fernando. O mythos da razão administrativa. Revista de Administração Pública, Rio de Janeiro, v. 3, p. 6-36, jul./set. 1993.

TENÓRIO, Fernando. Responsabilidade social empresarial: teoria e prática. 2. ed. Rio de Janeiro: Editora FGV, 2006.

TENÓRIO, Fernando. Tem a razão a administração? Revista de Administração Pública, Rio de janeiro, v. 24, n. 2, p. 5-9, fev./abr. 1990.

VALERIANO, José Carlos. Racionalidade nas práticas administrativas de uma cooperativa em Itabira/MG. FEAD-Minas Centro de Gestão Empreendedora, 2006.

YIN, Robert. Estudo de caso: planejamento e métodos. 3. ed. Porto Alegre: Bookman, 2005.

WEBER, Max. Economía y sociedad: esbozo de sociología comprensiva. México: Fondo de Cultura Económica, 1977.

O nome completo da autora foi corrigido de Miriam Soares Silva para Miriam Soares de Oliveira e Silva por solicitação do editor na data 09/03/2012. 